Société d'histoire de la révolution de 1848 et des

révolutions du XIXe siècle

8 | 1992

Jeunesses au XIXe siècle

\title{
Violence juvénile, violence familiale ? (1830-1880)
}

Frédéric Chauvaud

URL: http://journals.openedition.org/rh19/60

DOI: $10.4000 /$ rh19.60

ISSN: $1777-5329$

Publisher

La Société de 1848

Printed version

Date of publication: 1 June 1992

ISSN: 1265-1354

Electronic reference

Frédéric Chauvaud, «Violence juvénile, violence familiale ? (1830-1880) », Revue d'histoire du XIXe siècle [Online], 8 | 1992, Online since 09 September 2008, connection on 03 May 2019. URL : http:// journals.openedition.org/rh19/60 ; DOI : 10.4000/rh19.60

This text was automatically generated on 3 May 2019.

Tous droits réservés 


\section{Violence juvénile, violence familiale? (1830-1880)}

\section{Frédéric Chauvaud}

\section{ABSTRACTS}

No abstract available by now

Pas de résumé disponible actuellement

INDEX

Mots-clés: Jeunesse, Violence 